\title{
Biophysical and enzymatic properties of the simian and prototype foamy virus reverse transcriptases
}

\author{
Maximilian J Hartl ${ }^{1}$, Florian Mayr ${ }^{1}$, Axel Rethwilm², Birgitta M Wöhrl ${ }^{1 *}$
}

\begin{abstract}
Background: The foamy virus Pol protein is translated independently from Gag using a separate mRNA. Thus, in contrast to orthoretroviruses no Gag-Pol precursor protein is synthesized. Only the integrase domain is cleaved off from Pol resulting in a mature reverse transcriptase harboring the protease domain at the N-terminus (PR-RT). Although the homology between the PR-RTs from simian foamy virus from macaques (SFVmac) and the prototype foamy virus (PFV), probably originating from chimpanzee, exceeds $90 \%$, several differences in the biophysical and biochemical properties of the two enzymes have been reported (i.e. SFVmac develops resistance to the nucleoside inhibitor azidothymidine (AZT) whereas PFV remains AZT sensitive even if the resistance mutations from SFVmac PR-RT are introduced into the PFV PR-RT gene). Moreover, contradictory data on the monomer/dimer status of the foamy virus protease have been published.

Results: We set out to purify and directly compare the monomer/dimer status and the enzymatic behavior of the two wild type PR-RT enzymes from SFVmac and PFV in order to get a better understanding of the protein and enzyme functions. We determined kinetic parameters for the two enzymes, and we show that PFV PR-RT is also a monomeric protein.

Conclusions: Our data show that the PR-RTs from SFV and PFV are monomeric proteins with similar biochemical and biophysical properties that are in some aspects comparable with MLV RT, but differ from those of HIV-1 RT. These differences might be due to the different conditions the viruses are confronted with in dividing and nondividing cells.
\end{abstract}

\section{Background}

Foamy viruses (FVs) belong to the family retroviridae, but differ in several aspects from orthoretrovirinae: (a) reverse transcription occurs before the virus leaves the host cell [1,2], (b) the pol-gene is expressed from a separate mRNA [3-5], and (c) the viral protease is not cleaved off from the Pol polyprotein. Only the integrase is removed from Pol [6,7]. Thus, the FV reverse transcriptase harbors a protease, polymerase and RNase $\mathrm{H}$ domain (PR-RT) (for review see $[8,9]$ ).

Only recently, studies have focused on the biochemistry of the PR-RTs of FVs. Although the PR-RTs from simian foamy virus from macaques (SFVmac) and from the prototype foamy virus (PFV) exhibit more than

\footnotetext{
* Correspondence: birgitta.woehrl@uni-bayreuth.de

${ }^{1}$ Universität Bayreuth, Lehrstuhl für Struktur und Chemie der Biopolymere \& Research, Center for Biomacromolecules, 95440 Bayreuth, Germany
}

90\% sequence homology at the protein level $(79.5 \%$ identity; LALIGN, http://www.ch.embnet.org), some differences in their behavior have been reported. Bacterially expressed PFV PR-RT harbors many characteristics of orthoretroviral RTs; however, FV enzymes exhibit some peculiar features [10-16]. In comparison to human immunodeficiency virus type 1 (HIV-1) RT, PFV PR-RT appears to be a more processive polymerase [11]. This is probably due to differences in virus assembly. FV Pol packaging has been reported to require interactions of Pol with specific sequences in the RNA genome [17], and it has been suggested that there is a lower number of FV Pol molecules in the virus particle as compared to orthoretroviruses [11]. As a consequence, a highly processive polymerase is essential to enable synthesis of the complete double stranded genome.
C Biomed Central

() 2010 Hartl et al; licensee BioMed Central Ltd. This is an Open Access article distributed under the terms of the Creative Commons Attribution License (http://creativecommons.org/licenses/by/2.0), which permits unrestricted use, distribution, and reproduction in any medium, provided the original work is properly cited. 
One antiretroviral drug that has been shown to inhibit FV replication is azidothymidine (AZT) [1,18,19]. In in vivo experiments SFVmac acquired high resistance to AZT by four mutations within the RT sequence $[14,20]$. PFV, however, did not develop resistance to AZT, and the introduction of the SFVmac mutations into the PFV RT gene did not result in viruses resistant to the nucleoside inhibitor [20]. Regarding the high amino acid homology of the two enzymes, this result was not to be expected. In SFVmac, the mechanism of resistance is due to the removal of already incorporated AZT-monophosphate (AZTMP) in the presence of ATP and thus resembles that of HIV-1 RT [14,21,22].

It has been shown previously that retroviral PRs are only active as homodimers. To create the active center, each subunit of the homodimer contributes catalytic residues located in the conserved motif DT/SG [23]. However, SFVmac PR-RT behaves as a monomer in solution, but nevertheless exhibits PR activity. Catalytic PR activity could only be observed at $\mathrm{NaCl}$ concentrations of 2-3 M [15], indicating that hydrophobic interactions might promote dimerization. Furthermore, by prevalent methods the separately expressed $12.6 \mathrm{kDa}$ $\mathrm{PR}$ domain was also found to be monomeric but active [15]. Only further analyses using NMR paramagnetic relaxation enhancement proved that transient, lowly populated dimers are being formed (Hartl MJ, Schweimer K, Reger MH, Schwarzinger S, Bodem J, Rösch P, Wöhrl BM: Formation of transient dimers by a retroviral protease, submitted). Contradicting results were obtained by gel filtration analysis with a purified Cterminally extended $18 \mathrm{kDa}$ PR domain of PFV, which indicated that PFV PR might be dimeric [6].

To clarify these issues and to shed more light on the properties of SFVmac and PFV PR-RT, we set out to purify both enzymes from bacterial lysates and directly compare their secondary structure, oligomerization state, and activities.

\section{Results and Discussion}

\section{Protein purification}

Overexpression of PFV PR-RT in E. coli resulted in partial degradation by cellular proteases. Thus, we could not adopt the purification protocol established for SFVmac PR-RT [14]. Instead, we had to set up a new purification procedure for PFV PR-RT which includes $\mathrm{Ni}$-affinity followed by hydrophobic interaction chromatography to remove the PR-RT degradation products. The yields were much lower than for SFVmac PR-RT. Nevertheless, pure soluble protein (> 95\% purity, as judged from SDS-polyacrylamide gels) could be obtained.

\section{Biophysical properties}

To exclude that the purified PR-RTs are partially or completely unfolded, we analyzed the secondary structure of PFV and SFVmac PR-RT by circular dichroism (CD) spectroscopy. The shape of the CD spectra obtained for the two enzymes was highly similar, implying comparable ratios of $\alpha$-helices and $\beta$-strands (Fig. 1A). In both cases, the curves showed a broad minimum between $205 \mathrm{~nm}$ and $222 \mathrm{~nm}$, characteristic for a mixture of $\alpha$-helical and $\beta$-strand structures, and high ellipticity near $200 \mathrm{~nm}$. Thus, the spectra are indicative of predominantly folded proteins. Although the spectrum obtained for SFVmac PR-RT deviates slightly from that of PFV PR-RT, the calculated values (Table 1) confirm the accordance in the secondary structure contents of PFV and SFVmac PR-RT. However, crystal structure analyses will be necessary to obtain more information on the structural similarities and differences of the two enzymes. The three-dimensional structure will probably also shed more light on the differences between PFV and SFVmac PR-RT in developing AZT-resistance.

Contradicting data have been published on the monomer/dimer status of FV PRs. PFV PR expressed separately was suggested to be dimeric [6], whereas we have shown by various analyses, like size exclusion chromatography and analytical ultracentrifugation that the full length PR-RT protein as well as the separate PR domain of SFVmac are monomeric, and only transient PR dimers are being formed [15] (Hartl MJ, Schweimer K, Reger MH, Schwarzinger S, Bodem J, Rösch P, Wöhrl BM: Formation of transient dimers by a retroviral protease, submitted).

Previous results obtained by sucrose density gradient analyses with PR-RT purified from SFVmac particles also indicated that the protein is monomeric [24]. To clarify the monomer/dimer status of PFV PR-RT, we performed size exclusion chromatography (Fig. 1B). Our data revealed a single peak, which corresponded to a molecular mass of $85.4 \mathrm{kDa}$. This is in good agreement with the theoretical molecular mass of the monomeric PFV PR-RT of $86.5 \mathrm{kDa}$. Moreover, no dimer peak

Table $1 \mathrm{CD}$ values

\begin{tabular}{cccccc}
\hline enzyme & $\boldsymbol{\alpha}$-helix (\%) & $\boldsymbol{\beta}$-sheet (\%) & $\boldsymbol{\beta}$-turns (\%) & random coil (\%) & total (\%) \\
\hline PFV PR-RT & 22 & 30 & 20 & 27 & 99 \\
\hline SFVmac PR-RT & 22 & 29 & 20 & 28 & 99 \\
\hline
\end{tabular}




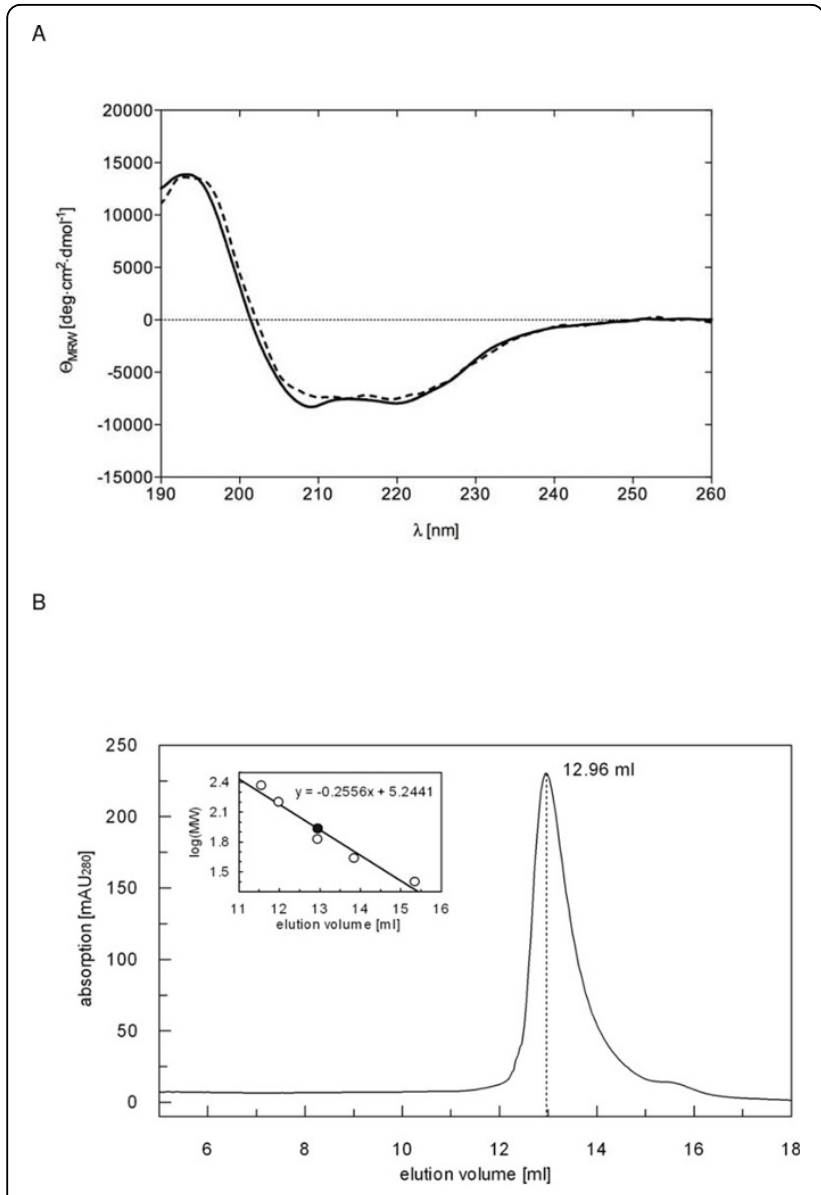

Figure 1 Biophysical properties of PFV and SFVmac PR-RT. (A) Far UV circular dichroism (CD) spectra of wild-type SFVmac (continuous line) and PFV PR-RT (dotted line) were acquired at $20^{\circ} \mathrm{C}$ using a band width of $1 \mathrm{~nm}$, a sensitivity of 100 mdeg and a data density of 5 points $/ \mathrm{nm}$ in a $0.1 \mathrm{~cm}$ cell with $0.5 \mu \mathrm{M}$ of each enzyme in $25 \mathrm{mM} \mathrm{Na}_{2} \mathrm{HPO}_{4} / \mathrm{NaH}_{2} \mathrm{PO}_{4} \mathrm{pH} 7.4$, and $5 \mathrm{mM} \mathrm{NaCl}$. (B) Size exclusion chromatography of PFV PR-RT using an S200 HR 10/30 column. The run was performed with $10 \mathrm{nmol}$ PFV PR-RT in $50 \mathrm{mM}$ $\mathrm{Na}_{2} \mathrm{HPO}_{4} / \mathrm{NaH}_{2} \mathrm{PO}_{4} \mathrm{pH} 7.4,300 \mathrm{mM} \mathrm{NaCl}$ and $0.5 \mathrm{mM}$ DTT. The inset shows the fit to the data obtained for the molecular masses of the standard proteins (open circles), which was used for the determination of the molecular mass of PFV PR-RT (closed circle).

could be detected, indicating that under native conditions PFV PR-RT, like SFVmac PR-RT is monomeric to a great extent (> 95\%).

\section{PR activity}

Activity of retroviral PRs is only achieved when a symmetric homodimer is formed, since each subunit provides a conserved aspartate residue to form the active center $[23,25,26]$. To detect residual PR activity we used a substrate, denoted GB1-GFP, that consists of a fusion protein between the immunoglobulin binding domain B1 of the streptococcal protein G (GB1) and the green fluorescent protein (GFP) enframing the natural
SFVmac Pol cleavage site YVVH $\downarrow$ CNTT. Although in PFV Pol the His is exchanged by Asn, this substrate could also be used for PFV PR-RT, because retroviral PRs are able to recognize different cleavage sites.

A concentration of $3 \mathrm{M} \mathrm{NaCl}$ was used in the assay since under these conditions SFVmac PR-RT revealed the highest PR activity, and no activity was detected when low salt concentrations (ca. $0.2-0.4 \mathrm{M} \mathrm{NaCl}$ ) were applied [15]. Fig. 2 illustrates that both proteins were capable of almost completely cleaving the provided substrate even though the offered sequence is different from the naturally occurring cleavage site in PFV Pol.

Size exclusion chromatography and PR activity assays revealed a new feature special to spumaretrovirinae. FVs appear to express a monomeric PR domain within the Pol polyprotein which is catalytically inactive. In vitro dimerization of the PR domain is inducible at high salt concentrations. This effect might be caused by a hydrophobic dimerization interface, which under high ionic strength disfavors the monomeric state.

Recently published results suggest that HIV-1 PR in the Gag-Pol precursor is only present as a transient dimer due to an inhibitory effect of the transframe region, which is located N-terminally of the PR domain [27]. Since there is no Gag-Pol fusion protein in FVs, an Nterminal extension of the PR does not exist. Thus, the regulation of the FV PR activity has to be different. We have shown recently, that SFVmac PR forms transient dimers at low salt concentrations. Obviously, in vivo PR activation cannot be achieved by increasing the $\mathrm{NaCl}$ concentration to $3 \mathrm{M}$, indicating that an additional cellular and/or viral factor must be involved in PR activation.

\section{Characteristics of polymerization}

A key step in the retroviral life cycle is the reverse transcription of the genomic RNA into double stranded (ds) DNA. For formation of dsDNA, the RT catalyzes RNAand DNA-dependent DNA polymerization to synthesize the $(-)$ and $(+)$-strand, respectively.

To further characterize the PR-RT enzymes, we performed polymerization assays on the homopolymeric poly $(\mathrm{rA}) /$ oligo $(\mathrm{dT})_{15}$ substrate and on heteropolymeric single-stranded M13 DNA. The incorporation of ${ }^{3} \mathrm{H}-$ TTP was used to determine Michaelis-Menten parameters. Comparison with values already published for SFVmac PR-RT for homopolymeric substrates revealed fairly similar $\mathrm{K}_{\mathrm{M}^{-}}$and $\mathrm{k}_{\text {cat }}$-values for the two enzymes. Moreover, the $\mathrm{K}_{\mathrm{M}}$-values for homo- and heteropolymeric substrates are comparable (Table 2) [14].

The $K_{M}$ values determined here for FV PR-RTs are ca. 5-30 fold higher than those published for HIV-1 RT [28-30]. A recent publication compares the pre-steadystate kinetics of PFV PR-RT with those of HIV-1 and 


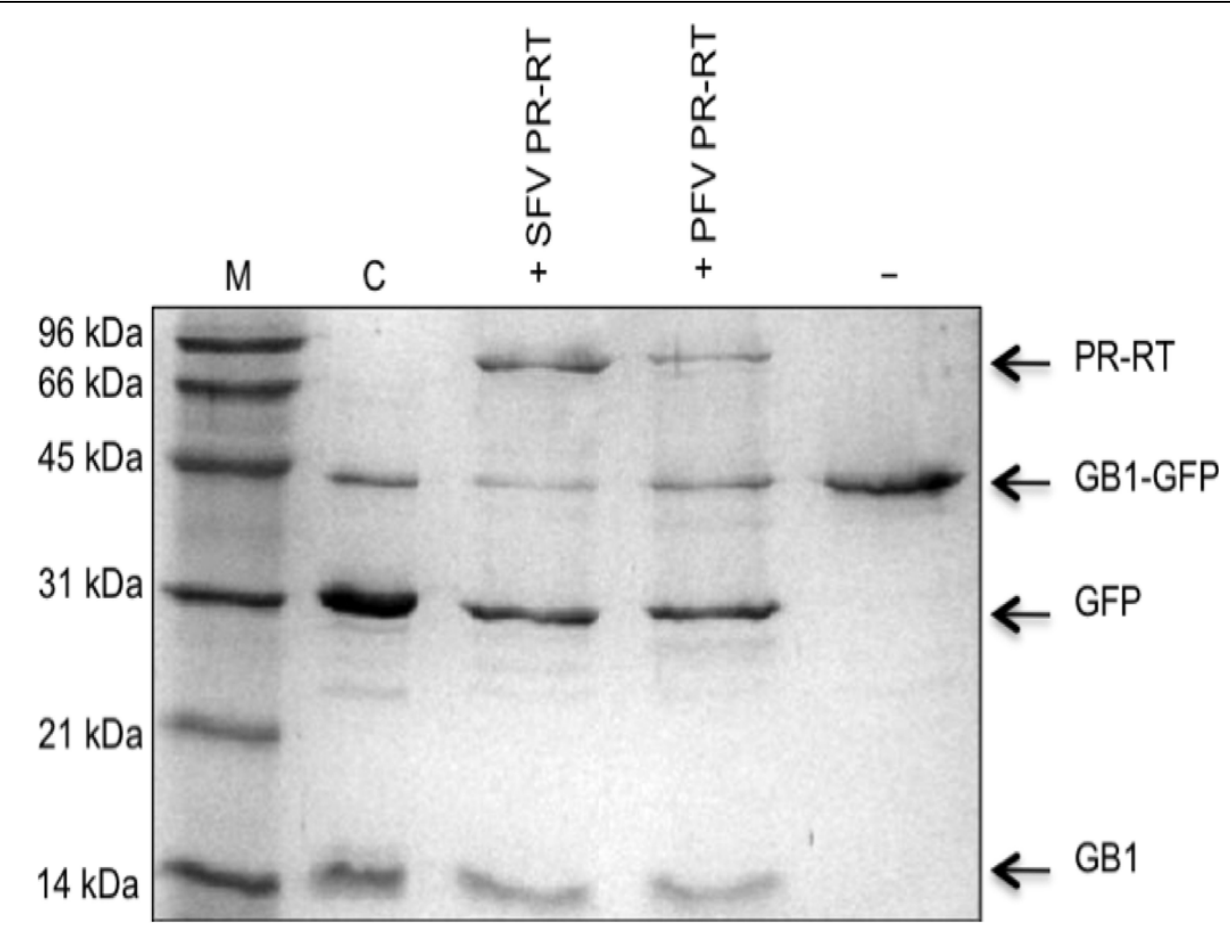

Figure 2 PR activity assay. Reaction products were analyzed by 19\% SDS-PAGE. $10 \mu \mathrm{M}$ GB1-GFP substrate harboring a FV PR cleavage site between GB1 and GFP was incubated with $10 \mu \mathrm{M}$ SFVmac PR-RT or PFV PR-RT, respectively, at $37^{\circ} \mathrm{C}$ for $16 \mathrm{~h}$ in reaction buffer ( $50 \mathrm{mM}$ $\mathrm{Na}_{2} \mathrm{HPO}_{4} / \mathrm{NaH}_{2} \mathrm{PO}_{4} \mathrm{pH} 7.4,0.5 \mathrm{mM}$ DTT, $3 \mathrm{M} \mathrm{NaCl}$ ). C, control, substrate cleavage with TEV protease; (-), uncleaved substrate; $\mathrm{M}$, molecular weight standard. The sizes of the standard proteins are indicated on the left.

murine leukemia virus (MuLV) RT [31]. Although the $k_{\mathrm{pol}}$ values of the three enzymes are similar, the dissociation constants $\left(\mathrm{K}_{\mathrm{D}}\right)$ for $\mathrm{dNTP}$ binding are about 10 80 fold higher with PFV PR-RT as compared to HIV-1 $\mathrm{RT}$, but are comparable to the affinities obtained for MuLV RT [31]. These kinetic data together with our results reveal different polymerization properties of HIV-1 RT and FV PR-RTs. The data imply that DNA polymerization of FV PR-RTs is poor at low dNTP concentrations. One reason for the differences observed might be the fact that in contrast to FV, HIV-1 can replicate in non-dividing cells, where dNTP concentrations are low. In such an environment, polymerization efficiency can be improved by RTs with high affinities for dNTPs [31].
A qualitative analysis of DNA polymerization was performed by using a heteropolymeric single stranded M13 DNA as a template together with a radioactively $5^{\prime}$ end labeled primer and saturating dNTP concentrations of $150 \mu \mathrm{M}$. The polymerization products were compared on a denaturing polyacrylamide/urea gel (Fig. 3). The results confirmed the kinetic data foreshadowed in Table 2, revealing a somewhat higher polymerization efficiency of PFV-PR-RT.

Since polymerization activities are also dependent on nucleic acid substrate affinities, we determined $K_{D^{-}}$ values of the two FV PR-RTs for DNA/RNA and DNA/DNA by fluorescence anisotropy. In each of these experiments a $24 / 40$ mer primer/template $(\mathrm{P} / \mathrm{T})$ substrate was used containing a fluorescent dye

Table 2 Kinetic parameters of the polymerization activities of SFVmac and PFV PR-RT

\begin{tabular}{|c|c|c|c|c|c|c|}
\hline enzyme & $\begin{array}{c}\mathrm{K}_{\mathrm{D}} \\
\text { DNA/RNA } \\
(\mathrm{nM}) \\
\end{array}$ & $\begin{array}{c}\mathrm{K}_{\mathrm{D}} \\
\text { DNA/DNA } \\
(\mathrm{nM}) \\
\end{array}$ & $\begin{array}{c}\mathrm{K}_{\mathrm{M}}{ }^{1)} \\
(\mathrm{TTP} / \mathrm{rAdT}) \\
(\mu \mathrm{M}) \\
\end{array}$ & $\begin{array}{c}\mathrm{k}_{\mathrm{cat}}{ }^{1)} \\
(\mathrm{TTP} / \mathrm{rAdT}) \\
\left(\mathrm{s}^{-1}\right) \\
\end{array}$ & $\begin{array}{c}\mathrm{K}_{\mathrm{M}}^{2)} \\
(\mathrm{dNTPs} / \mathrm{M} 13) \\
(\mu \mathrm{M}) \\
\end{array}$ & $\begin{array}{c}k_{\text {cat }}^{2} \\
(\mathrm{dNTPs} / \mathrm{M} 13) \\
\left(\mathrm{s}^{-1}\right)\end{array}$ \\
\hline PFV PR-RT & $9.9( \pm 1.6)$ & $44.4( \pm 3.0)$ & $45( \pm 12)$ & $7.1( \pm 0.9)$ & $46( \pm 9)$ & $3( \pm 0.3)$ \\
\hline SFVmac PR-RT & $32.4( \pm 4.2)^{3)}$ & $36.4( \pm 2.4)^{3)}$ & $40.1( \pm 4.0)^{3)}$ & $5.5( \pm 0.3)^{4)}$ & $45( \pm 3)$ & $4( \pm 0.1)$ \\
\hline
\end{tabular}

\footnotetext{
1) $\mathrm{K}_{M}$ and $\mathrm{k}_{\text {cat }}$-values, respectively, determined for TTP on the homopolymeric substrate poly(rA)/oligo(dT).

2) $K_{M}$ and $k_{c a t}$-values, respectively, determined for dNTPs on a heteropolymeric single stranded M13 substrate

3) Data adopted from [14]

4) $v_{\max }-\mathrm{value}$ used for $\mathrm{k}_{\mathrm{cat}}$ calculation derived from [14].
} 


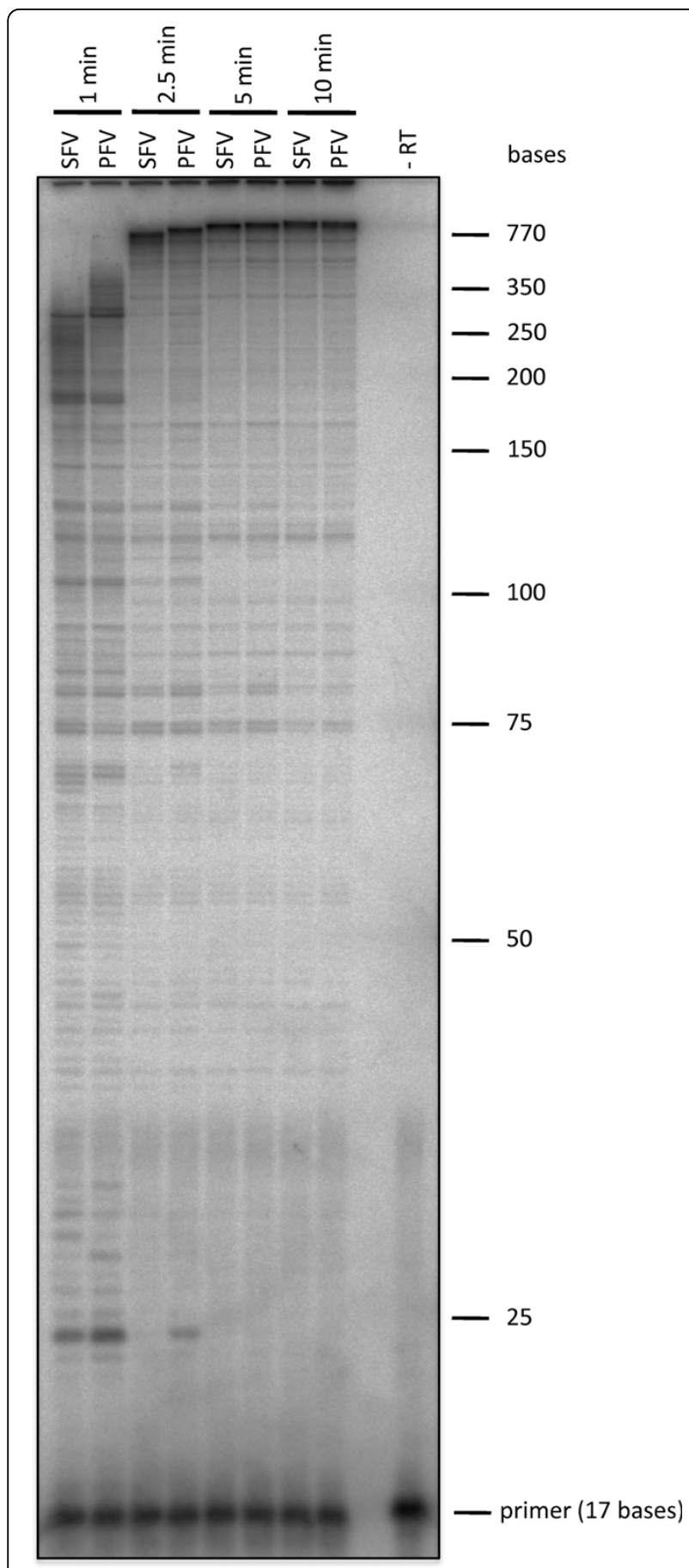

Figure 3 DNA-dependent DNA polymerase activity on a heteropolymeric substrate. Reactions were carried out at $37^{\circ} \mathrm{C}$ for the times indicated on top with $6 \mathrm{nM}$ of the $\mathrm{M} 13 \mathrm{P} / \mathrm{T}$ substrate, 85 nM of PFV or SFV PR-RT and $150 \mu \mathrm{M}$ of each dNTP, analyzed by denaturing gel electrophoresis on a 10\% sequencing gel and visualized by phosphoimaging. DNA size markers are marked on the right. - RT, assay without enzyme;
(Dy-647) at the 5 end of the template strand (Table 2, Fig. 4). For both enzymes, the affinity for the DNA/ RNA P/T appeared to be higher than for DNA/DNA. This effect was far more pronounced for PFV PR-RT with a 4-fold lower $K_{D}$-value for the DNA/RNA substrate. Comparison with HIV-1 RT shows an unexpected difference, i.e. the affinities of HIV-1 RT for nucleic acid substrates are much higher. For DNA/ DNA or DNA/RNA substrates $K_{D}$-values of approximately $2 \mathrm{nM}$ have been determined [32-34].

\section{RNase $\mathrm{H}$ activity}

The third enzymatic activity associated with PR-RT is its RNase $\mathrm{H}$ activity, which is responsible for degradation of the RNA strand of an RNA/DNA hybrid and is indispensable in the reverse transcription process.

Polymerization-independent RNase $\mathrm{H}$ activity was tested on two different substrates. First, Michaelis-Menten-parameters were determined on a blunt-ended RNA/DNA substrate containing a fluorescent dye on the 3' end of the RNA and a quencher on the 5' end of the DNA. Upon cleavage of the RNA the fluorescent dye is released from the quencher resulting in an increase in fluorescence intensity. By varying substrate concentrations, $\mathrm{K}_{\mathrm{M}^{-}}$and $\mathrm{k}_{\mathrm{cat}}$-values for RNase $\mathrm{H}$ activities were calculated (Table 3). SFVmac and PFV PR-RT showed $\mathrm{K}_{\mathrm{M}^{-}}$values of $18.1 \mathrm{nM}$ and $17.1 \mathrm{nM}$, respectively. These are in the range of HIV-1 RT (25 nM) [35]

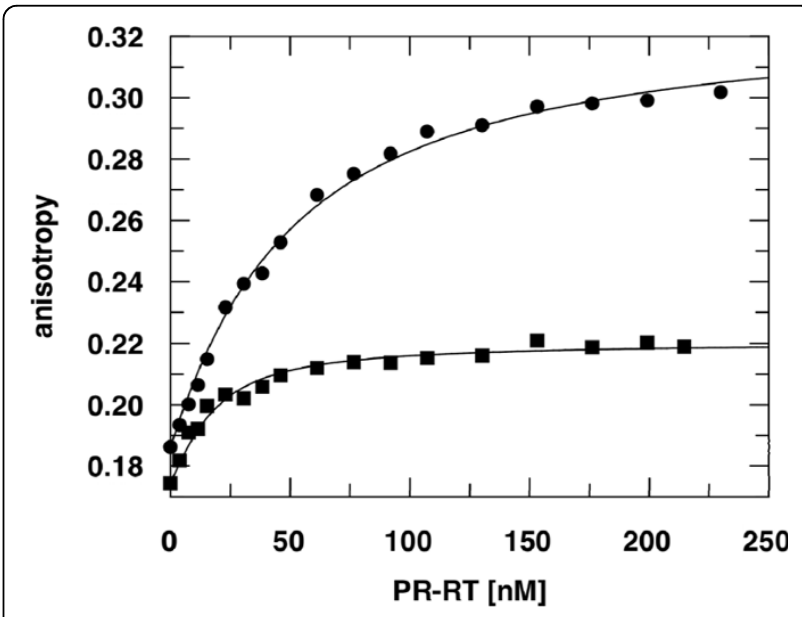

Figure 4 Determination of $\mathrm{K}_{\mathrm{D}}$-values by fluorescence anisotropy measurements. $15 \mathrm{nM}$ of a fluorescently labeled DNA/ DNA (black circle) or DNA/RNA (black square) P/T substrate was titrated with PFV PR-RT at $25^{\circ} \mathrm{C}$. The curves show the best fit to a two component binding equation [14] describing the binding equilibrium with $K_{D}$-values shown in Table 2. 
Table 3 Kinetic parameters of the RNase $\mathrm{H}$ activities of SFVmac and PFV PR-RT

\begin{tabular}{lcc}
\hline enzyme & $\mathbf{K}_{\mathbf{M}}$ & $\mathbf{k}_{\mathbf{c a t}}\left(\mathbf{s}^{-\mathbf{1}}\right)$ \\
\hline PFV PR-RT & $17.1( \pm 1.2)$ & $0.017( \pm 0.0003)$ \\
\hline SFVmac PR-RT & $18.1( \pm 0.6)$ & $0.020( \pm 0.0003)$ \\
\hline
\end{tabular}

and E. coli RNase H (16 - $130 \mathrm{nM}$, depending on the substrate) [36]. Provided that indeed FV PR-RTs are less abundant in the virus particle, it is remarkable that the FV RNase $H$ activities were not higher than those of HIV-1 RT.

To determine the endonucleolytic RNase $\mathrm{H}$ cleavage sites of the two PR-RTs qualitatively, a 40 mer RNA hybridized to a 24 mer DNA was used (Fig. 5). A fluorescent dye at the 5 ' end of the RNA allowed visualization of the cleavage products after separation on $15 \%$ sequencing gels. Our time course experiments indicated that with both enzymes a primary endonucleolytic cleavage at position -19 was followed by a $3^{\prime}>5^{\prime}$ directed processing reaction leading to shorter RNA products (Fig. 5). Primary RNase $\mathrm{H}$ cleavage sites in the RNA at positions 15 -20 nucleotides away from the primer terminus of the hybrid were also detected for the RTs of orthoretrovirinae like HIV-1 and RSV [37-42]. They are directed by the 3'-end of the DNA-primer which binds to the active site of the polymerase $[43,44]$. While RSV RT appears to lack a 3' > 5' directed processing activity [37], SFVmac and PFV PR-RTs (Figure 5B) as well as HIV-1 and MoMLV RTs degrade the RNA to 8 mers or smaller products $[41,45]$.

\section{Conclusions}

Our data reveal small differences of FV PR-RTs in their catalytic activities and biophysical properties. The $\mathrm{K}_{\mathrm{M}^{-}}$ values determined for HIV-1 RT are 5-30 fold lower than those for FV PR-RTs. These deviations in kinetic behavior might be based on the fact that HIV-1 can replicate in non-dividing cells. Remarkably, both FV PRRTs are monomeric in solution, implying that transient dimers need to be formed in order to obtain PR activity. Transient dimerization has been demonstrated recently for SFVmac PR and was suggested to play a role in the regulation of a timely activation of PR activity (Hartl MJ, Schweimer K, Reger MH, Schwarzinger S, Bodem J, Rösch P, Wöhrl BM: Formation of transient dimers by a retroviral protease, submitted). Small structural and consequently catalytic variations between the two FV PRRTs might account for the differences observed (e.g. in the resistance to the nucleoside inhibitor AZT.) Further structural and functional analyses will be necessary to elucidate these findings.

\section{Methods}

Plasmid construction and protein purification

For SFVmac PR-RT, gene expression and protein purification were performed as described previously [14]. The plasmid pET101TOPO-PFV-PR-RT-6His was constructed using the Champion ${ }^{\mathrm{Tm}} \mathrm{pET}$ Directional $\mathrm{TOPO}^{\circ}$ Expression kit (Invitrogen, Darmstadt, Germany). The Nterminus of the PFV PR-RT starts with the amino acids MNPLQLLQPL corresponding to the N-terminus of the $\mathrm{PR}$ gene. The $\mathrm{C}$-terminus contains a $6 \times \mathrm{His}$ tag and exhibits the following amino acid sequence: ATQGSYVVNA-6His. The plasmid was transformed into the Escherichia coli (E. coli) strain BL21 (DE3) pREP4: GroESL [46], expressing E. coli chaperone proteins to facilitate folding of heterologous proteins. Cells were grown at $37^{\circ} \mathrm{C}$ in LB medium supplemented with $100 \mu \mathrm{g} /$ $\mathrm{ml}$ ampicillin and $34 \mu \mathrm{g} / \mathrm{ml}$ kanamycin to an optical density of $600 \mathrm{~nm}\left(\mathrm{OD}_{600}\right)$ of ca. 0.8 . The temperature was reduced to $16^{\circ} \mathrm{C}$ until an $\mathrm{OD}_{600}$ of ca. 1.0 was reached. Expression of the recombinant PFV PR-RT-6His gene was then induced by the addition of $0.2 \mathrm{mM}$ isopropylthiogalactoside (IPTG) at $16^{\circ} \mathrm{C}$ over night. Cells were harvested by centrifugation at $5000 \mathrm{~g}$ for $20 \mathrm{~min}$ at $4^{\circ} \mathrm{C}$.

\section{Purification of SFVmac and PFV PR-RT}

SFVmac PR-RT was purified as described previously [14]. PFV PR-RT was purified as follows by a combination of Ni-affinity and hydrophobic interaction chromatography:

\section{Ni-NTA affinity chromatography}

Cells were resuspended in $50 \mathrm{mM} \mathrm{Na-phosphate} \mathrm{pH} 7.4$, $300 \mathrm{mM} \mathrm{NaCl}, 10 \mathrm{mM}$ imidazole, $0.5 \mathrm{mM}$ dithiothreitol (DTT). After addition of lysozyme, DNase I and one protease inhibitor cocktail tablet (Complete, EDTA-free, Roche Diagnostics GmbH, Mannheim) the suspension was stirred on ice for $30 \mathrm{~min}$. After cell lysis using a microfluidizer (Microfluidics, Newton, MA, USA) the suspension was centrifuged at $19100 \mathrm{~g}$ for $30 \mathrm{~min}$ at $4^{\circ}$ C. Purification of the protein was performed by a step gradient applying increasing concentrations of up to 500 mM imidazole on a HisTrap column (His Trap, GE Healthcare, München, Germany).

\section{Hydrophobic interaction chromatography}

Fractions containing PFV PR-RT were pooled and dialyzed (Spectra/Por, MWCO $50000 \mathrm{Da}$ ) twice for at least $2 \mathrm{~h}$ against $50 \mathrm{mM}$ Na-phosphate $\mathrm{pH} 7.4,300 \mathrm{mM}$ $\mathrm{NaCl}, 1 \mathrm{M}\left(\mathrm{NH}_{4}\right)_{2} \mathrm{SO}_{4}$ and $0.5 \mathrm{mM} \mathrm{DTT}$ and then loaded onto a $5 \mathrm{ml}$ butyl column (ButylFF, GE Healthcare, München, Germany). The protein was eluted by applying a step gradient from $1 \mathrm{M}\left(\mathrm{NH}_{4}\right)_{2} \mathrm{SO}_{4}$ and 300 $\mathrm{mM} \mathrm{NaCl}$ to $0 \mathrm{M}\left(\mathrm{NH}_{4}\right)_{2} \mathrm{SO}_{4}$ and $0 \mathrm{M} \mathrm{NaCl}$. After electrophoresis of the fractions on $10 \%$ SDS-polyacrylamide gels the relevant fractions were concentrated with 


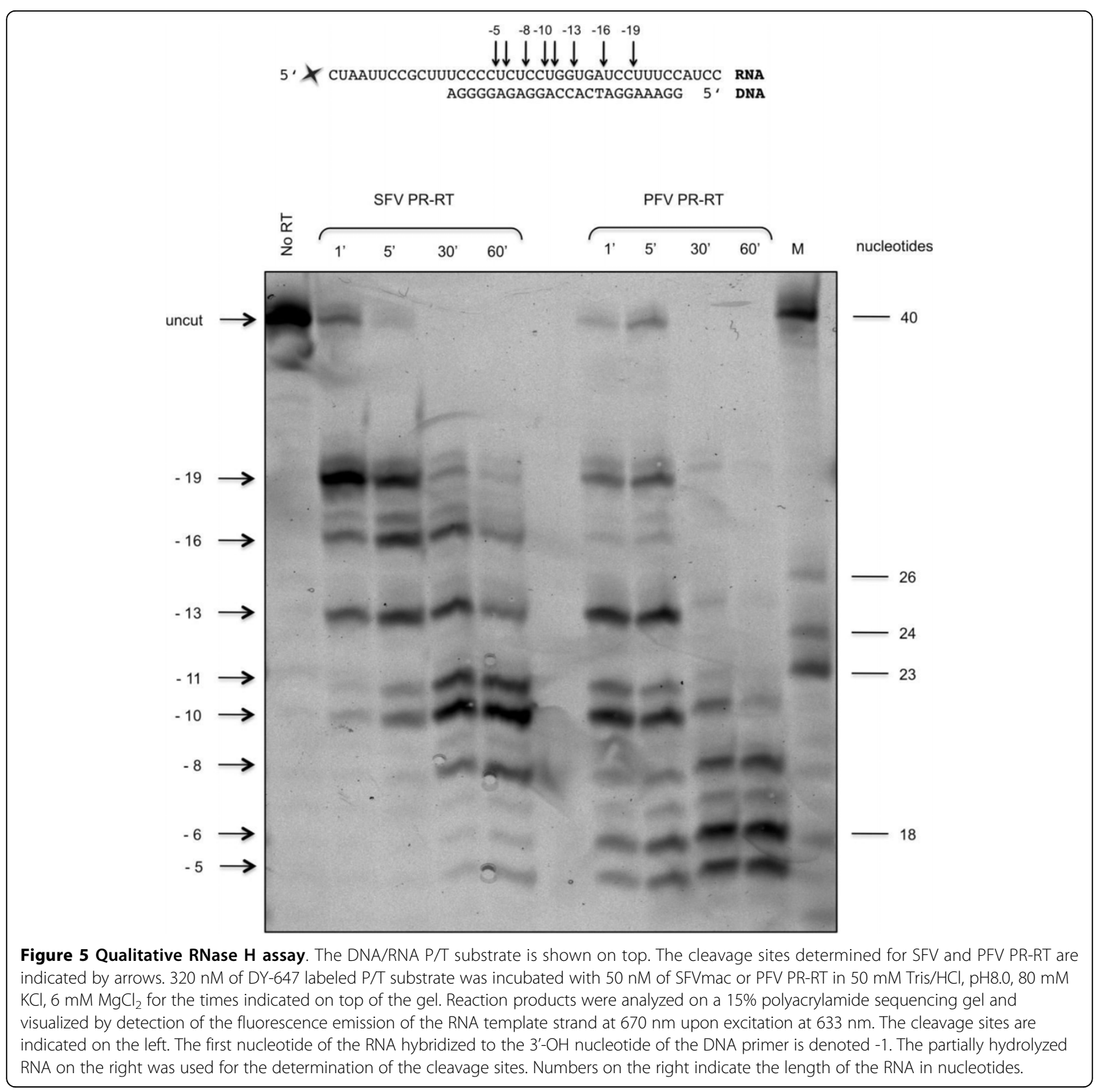

Vivaspin concentrators (MWCO $10000 \mathrm{Da})$ to a volume of $200 \mu \mathrm{l}$ and dialyzed against $50 \mathrm{mM} \mathrm{Na-phos-}$ phate $\mathrm{pH} 7.4,100 \mathrm{mM} \mathrm{NaCl} 0.5 \mathrm{mM}$ DTT.

Analyses using circular dichroism (CD) spectra and size exclusion chromatography were performed with freshly purified SFVmac and PFV PR-RT. For PR, polymerization and RNase $\mathrm{H}$ measurements the PFV PR-RT was dialyzed (Spectra/Por, MWCO $50000 \mathrm{Da}$ ) against $50 \mathrm{mM}$ Na-phosphate pH 7.4, $100 \mathrm{mM} \mathrm{NaCl}, 0.5 \mathrm{mM}$ DTT and 15\% glycerol over night, the glycerol concentration was then increased to $50 \%$ and the protein stored at $-20^{\circ} \mathrm{C}$.

\section{Peptide mass fingerprint (PMF) analysis}

Protein bands of ca. $1 \mathrm{~mm} \times 3 \mathrm{~mm}$ were excised from $10 \%$ SDS-polyacrylamide gels and the integrity and identity of PFV PR-RT was confirmed by peptide mass fingerprinting (ZMMK Köln, Zentrale Bioanalytik, Germany).

\section{Circular dichroism}

Far UV circular dichroism (CD) spectra of wild-type SFVmac and PFV PR-RT were acquired at $20^{\circ} \mathrm{C}$ using a Jasco J-810 spectropolarimeter (Japan Spectroscopic, Gross-Umstadt, Germany) at a band width of $1 \mathrm{~nm}$, a sensitivity of 100 mdeg and a data density of 5 points/ 
$\mathrm{nm}$ in a $0.1 \mathrm{~cm}$ cell. $0.5 \mu \mathrm{M}$ of each enzyme was measured in $25 \mathrm{mM} \mathrm{Na}$-phosphate $\mathrm{pH} 7.4$ and $5 \mathrm{mM} \mathrm{NaCl}$. At least 12 scans in the range between 260 and $190 \mathrm{~nm}$ were averaged for each measurement, and the resulting spectrum was smoothed and normalized to a mean residual weight ellipticity $\left[\Theta_{\mathrm{MRW}}\right]\left(\mathrm{deg} \cdot \mathrm{cm}^{2} \cdot \mathrm{dmol}^{-1}\right)$ using Jasco Spectra Manager Software. For secondary structure predictions based on the $C D$ data the program CDSSTR (Dichroweb) [14,27] was used.

\section{Size exclusion chromatography}

For analytical gel filtration of PFV PR-RT a Superdex 200 HR 10/30 column (GE Healthcare, Munich, Germany) calibrated with catalase (232 kDa), aldolase (158 kDa), ovalbumine (43 kDa) and chymotrypsinogen (25 kDa) (GE Healthcare, Munich, Germany) was used at a flow rate of $0.5 \mathrm{ml} / \mathrm{min}$. The column was loaded with $10 \mathrm{nmol}$ PFV PR-RT in $50 \mathrm{mM} \mathrm{Na} \mathrm{HPO}_{4} /$ $\mathrm{NaH}_{2} \mathrm{PO}_{4} \mathrm{pH}$ 7.4, $300 \mathrm{mM} \mathrm{NaCl}$ and $0.5 \mathrm{mM}$ DTT.

\section{PR activity assay}

PR activity was measured as described before using a substrate which contained the SFVmac Pol cleavage site ATQGSYVVH $\downarrow$ CNTTP that can also be used by PFV PR-RT. Control digests with TEV protease were performed with the same substrate since it harbors a TEV cleavage site adjacent to the FV PR cleavage site [15].

\section{Polymerization assays}

RNA-dependent DNA polymerase activity was quantitated on a poly(rA)/oligo(dT) 15 substrate $(0.2 \mathrm{U} / \mathrm{ml}$ ) (Roche Diagnostics $\mathrm{GmbH}$, Mannheim, Germany) in a standard assay (30 $\mu$ l reaction volume) as described previously [14]. For the determination of $\mathrm{K}_{\mathrm{M}}, \mathrm{v}_{\max }$ and $\mathrm{k}_{\mathrm{cat}}$ values, reactions were performed with increasing concentrations of TTP of $25,50,75,125$ or $250 \mu \mathrm{M}$. For the determination of kinetic parameters on a heteropolymeric substrate 100 nM of single stranded M13mp18 DNA and 15 nM of PRRT was used. dNTP concentrations of 25, 50, 75, 125 and $250 \mu \mathrm{M}$ were added, using [3H]-TTP $(3000 \mathrm{Ci} / \mathrm{mmol}$, Hartmann Analytic $\mathrm{GmbH}$, Braunschweig, Germany) as a tracer. $K_{M}$-values were calculated by linear regression using Eadie-Hofstee plots. $\mathrm{k}_{\text {cat }}$ is defined as $\mathrm{v}_{\max }$ /enzyme concentration. Qualitative DNA polymerization assays on denaturing polyacrylamide/urea gels using single stranded M13mp18 DNA as a substrate were performed as described previously [14].

\section{Fluorescence anisotropy measurements}

Fluorescence equilibrium titrations were performed to determine the dissociation constants $\left(K_{D}\right)$ for nucleic acid binding with a $24 / 40$ mer DNA/DNA or DNA/ RNA primer/template $(\mathrm{P} / \mathrm{T})$. Experiments and data fitting were carried out as described [14] with15 nM fluorescently labeled $\mathrm{P} / \mathrm{T}$ at $25^{\circ} \mathrm{C}$.

\section{RNase $\mathrm{H}$ activity assays Substrate preparation}

The RNA-strand 5'-CCG AUG GCU CUC CUG GUG AUC CUU UCC-6-FAM (6-carboxy-fluorescein) and the DNA-strand 5'-Dabcyl-GGA AAG GAT CAC CAG GAG AG were synthesized by biomers.net (Ulm, Germany). The hybrid was formed by mixing the two oligonucleotides at a ratio of 1:1.2 respectively in $20 \mathrm{mM}$ Tris/ $\mathrm{HCl} \mathrm{pH} 8.0$ and $20 \mathrm{mM} \mathrm{NaCl}$, followed by heating at $95^{\circ} \mathrm{C}$ for $2 \mathrm{~min}$ and cooling down to room temperature over a time period of $2 \mathrm{~h}$. The resulting substrate was stored in aliquots at $-20^{\circ} \mathrm{C}$.

\section{RNase $\mathrm{H}$ enzyme kinetics}

Steady-state fluorescence measurements were performed at $25^{\circ} \mathrm{C}$ on a Fluorolog-Tau-3 spetrofluorometer (HORIBA Jobin Yvon GmbH, Unterhaching, Germany). The assay was carried out in a total volume of $1.2 \mathrm{ml}$ containing $50 \mathrm{mM}$ Tris $/ \mathrm{HCl} \mathrm{pH} \mathrm{8.0,80} \mathrm{mM} \mathrm{KCl,} 6 \mathrm{mM}$ $\mathrm{MgCl}_{2}$ and a final concentration of $1 \mathrm{nM}$ PR-RT. To determine the Michaelis-Menten kinetic parameters the DNA-dabcyl/RNA-6-FAM P/T concentration was varied from 10 to $200 \mathrm{nM}$. Cleavage of the RNA in the hybrid leads to dissociation of a fluorescein labeled RNA fragment from the dabcyl quencher and thus to a fluorescence increase. Upon excitation of the substrate at 495 $\mathrm{nm}$ an increase in fluorescence emission can be detected at $520 \mathrm{~nm}$. The maximum change in fluorescence intensity and thus complete substrate cleavage was determined by incubating the hybrid with a large excess of PR-RT (250 nM). Initial rates were calculated using the linear slope of the reaction progress curve where less than $5 \%$ of substrate was cleaved. Values for kinetic parameters $\left(K_{M}\right.$ and $\left.v_{\max }\right)$ were obtained by linear Eadie-Hofstee regression of the Michaelis-Menten equation $\mathrm{V}_{0}=\mathrm{V}_{\text {max }} \cdot\left[\mathrm{S}_{0}\right] /\left(\mathrm{K}_{\mathrm{m}}+\left[\mathrm{S}_{0}\right]\right) \cdot \mathrm{k}_{\text {cat }}$ is defined as $\mathrm{v}_{\max } /$ enzyme concentration.

\section{Qualitative RNase H assay}

The gelelectrophoretic assay used a 5' fluorescently labeled RNA-oligonucleotide (5'- [DY-647]-CUA AUU CCG CUU UCC CCU CUC CUG GUG AUC CUU UCC AUC C; biomers.net, Ulm, Germany), which was purified on a $20 \%$ denaturing polyacrylamide gel and then annealed to the unlabeled DNA-oligonucleotide 5'-GGA AAG GAT CAC CAG GAG AGG GGA (biomers.net, Ulm, Germany). The hybrid was formed by mixing $2 \mu \mathrm{M}$ Dye647-RNA with 2.4 $\mu \mathrm{M}$ DNA primer in $20 \mathrm{mM}$ Tris/ $\mathrm{HCl} \mathrm{pH} 8.0$ and $20 \mathrm{mM}$ $\mathrm{NaCl}$, followed by heating at $95^{\circ} \mathrm{C}$ for 2 min and cooling at room temperature over a time period of $2 \mathrm{~h}$. The RNase $\mathrm{H}$ reaction was performed at $37^{\circ} \mathrm{C}$ in a total volume of $30 \mu \mathrm{l}$ in $50 \mathrm{mM}$ Tris/ $\mathrm{HCl} \mathrm{pH} \mathrm{8.0,80} \mathrm{mM} \mathrm{KCl}$ and $6 \mathrm{mM} \mathrm{MgCl}_{2}$ with $320 \mathrm{nM} \mathrm{P} / \mathrm{T}$ substrate. The reaction was initiated by 
the addition of $50 \mathrm{nM}$ PR-RT. Aliquots were removed at different time points and analyzed by electrophoresis on a $15 \%$ polyacrylamide sequencing gel. Products were visualized by fluorescence emission at $670 \mathrm{~nm}$ upon excitation at $633 \mathrm{~nm}$ using a fluorescence laser scanner (FLA 3000, raytest, Straubenhardt, Germany).

\section{Abbreviations}

CD: circular dichroism; E. coli: Escherichia coli; 6-FAM: 6-carboxy-fluorescein; GB1: immunoglobulin binding domain B1 of streptococcal protein G; GFP: green fluorescent protein; HIV-1: human immunodeficiency virus type 1 ; IPTG: isopropyl-thiogalactoside; LTR: long terminal repeat; MuLV: murine leukemia virus; PMF: peptide mass fingerprint; PFV: prototype foamy virus; SFVmac: simian foamy virus from macaques.

\section{Acknowledgements}

The project was funded by the Deutsche Forschungsgemeinschaft DFG (Re627/8-1, SFB 479, Wo630/7-3), the Graduate School in the Elite Network of Bavaria "Lead Structures of Cell Functions" and the University of Bayreuth.

\section{Author details}

${ }^{1}$ Universität Bayreuth, Lehrstuhl für Struktur und Chemie der Biopolymere \& Research, Center for Biomacromolecules, 95440 Bayreuth, Germany. ${ }^{2}$ Universität Würzburg, Institut für Virologie und Immunbiologie, 97078 Würzburg, Germany.

\section{Authors' contributions}

BMW conceived and coordinated the study. MJH and FM performed the experiments, AR provided reagents and participated in designing the experiments. BMW and MJH wrote the paper. All authors read and approved the manuscript.

\section{Competing interests}

The authors declare that they have no competing interests.

Received: 30 September 2009

Accepted: 29 January 2010 Published: 29 January 2010

\section{References}

1. Moebes A, Enssle J, Bieniasz PD, Heinkelein M, Lindemann D, Bock M, McClure MO, Rethwilm A: Human foamy virus reverse transcription that occurs late in the viral replication cycle. J Virol 1997, 71:7305-7311.

2. Yu SF, Sullivan MD, Linial ML: Evidence that the human foamy virus genome is DNA. J Virol 1999, 73:1565-1572.

3. Enssle J, Jordan I, Mauer B, Rethwilm A: Foamy virus reverse transcriptase is expressed independently from the gag protein. Proc Natl Acad Sci USA 1996, 93:4137-4141.

4. Jordan I, Enssle J, Guttler E, Mauer B, Rethwilm A: Expression of human foamy virus reverse transcriptase involves a spliced pol mRNA. Virology 1996, 224:314-319.

5. Löchelt M, Flügel RM: The human foamy virus pol gene is expressed as a pro-pol polyprotein and not as a gag-pol fusion protein. J Virol 1996, 70:1033-1040.

6. Pfrepper Kl, Rackwitz HR, Schnölzer M, Heid H, Löchelt M, Flügel RM: Molecular characterization of proteolytic processing of the pol proteins of human foamy virus reveals novel features of the viral protease. J Virol 1998, 72:7648-7652.

7. Roy J, Linial ML: Role of the foamy virus pol cleavage site in viral replication. J Virol 2007, 81:4956-4962.

8. Linial M: Foamy viruses. Fields Virology Lippincott Williams \& Wilkins, PhiladelphiaKnipe DM, Howley PM 2007, 2245-2262.

9. Rethwilm A: Foamy viruses. Topley \& Wilson's Microbiology and Microbial Infections - Virology London:Hodder Arnoldter Meulen V, Mahy BWJ 2005, 1304-1321.

10. Boyer PL, Stenbak CR, Clark PK, Linial ML, Hughes SH: Characterization of the polymerase and RNase $\mathrm{H}$ activities of human foamy virus reverse transcriptase. J Virol 2004, 78:6112-6121.
11. Rinke CS, Boyer PL, Sullivan MD, Hughes SH, Linial ML: Mutation of the catalytic domain of the foamy virus reverse transcriptase leads to loss of processivity and infectivity. J Virol 2002, 76:7560-7570.

12. Kögel D, Aboud M, Flügel RM: Molecular biological characterization of the human foamy virus reverse transcriptase and ribonuclease $\mathrm{H}$ domains. Virology 1995, 213:97-108.

13. Kögel D, Aboud M, Flügel RM: Mutational analysis of the reverse transcriptase and ribonuclease $\mathrm{H}$ domains of the human foamy virus. Nucleic Acids Res 1995, 23:2621-2625.

14. Hartl MJ, Kretzschmar B, Frohn A, Nowrouzi A, Rethwilm A, Wöhrl BM: AZT resistance of simian foamy virus reverse transcriptase is based on the excision of AZTMP in the presence of ATP. Nucleic Acids Res 2008, 36:1009-1016.

15. Hartl MJ, Wöhrl BM, Rösch P, Schweimer K: The solution structure of the simian foamy virus protease reveals a monomeric protein. J Mol Biol 2008, 381:141-149.

16. Boyer PL, Stenbak CR, Hoberman D, Linial ML, Hughes SH: In vitro fidelity of the prototype primate foamy virus (PFV) RT compared to HIV-1 RT. Virology 2007, 367:253-264.

17. Peters $K$, Wiktorowicz T, Heinkelein M, Rethwilm A: RNA and protein requirements for incorporation of the pol protein into foamy virus particles. J Virol 2005, 79:7005-7013.

18. Rosenblum LL, Patton G, Grigg AR, Frater AJ, Cain D, Erlwein O, Hill CL, Clarke JR, McClure MO: Differential susceptibility of retroviruses to nucleoside analogues. Antivir Chem Chemother 2001, 12:91-97.

19. Lee CC, Ye F, Tarantal AF: Comparison of growth and differentiation of fetal and adult rhesus monkey mesenchymal stem cells. Stem Cells Dev 2006, 15:209-220.

20. Kretzschmar B, Nowrouzi A, Hartl MJ, Gartner K, Wiktorowicz T, Herchenröder O, Kanzler S, Rudolph W, Mergia A, Wöhrl B, Rethwilm A: AZT-resistant foamy virus. Virology 2008, 370:151-157.

21. Meyer PR, Matsuura SE, Mian AM, So AG, Scott WA: A mechanism of AZT resistance: $A n$ increase in nucleotide-dependent primer unblocking by mutant HIV-1 reverse transcriptase. Mol Cell 1999, 4:35-43.

22. Meyer PR, Matsuura SE, So AG, Scott WA: Unblocking of chain-terminated primer by HIV-1 reverse transcriptase through a nucleotide-dependent mechanism. Proc Natl Acad Sci USA 1998, 95:13471-13476.

23. Dunn BM, Goodenow MM, Gustchina A, Wlodawer A: Retroviral proteases. Genome Biol 2002, 3:1465-6914.

24. Benzair AB, Rhodes-Feuillette A, Emanoil-Ravicovitch R, Peries J: Reverse transcriptase from simian foamy virus serotype 1: Purification and characterization. J Virol 1982, 44:720-724.

25. Wlodawer A, Gustchina A: Structural and biochemical studies of retroviral proteases. Biochim Biophys Acta 2000, 1477:16-34.

26. Wlodawer A, Miller M, Jaskolski M, Sathyanarayana BK, Baldwin E, Weber IT, Selk LM, Clawson L, Schneider J, Kent SB: Conserved folding in retroviral proteases: Crystal structure of a synthetic HIV-1 protease. Science 1989, 245:616-621.

27. Tang C, Louis JM, Aniana A, Suh JY, Clore GM: Visualizing transient events in amino-terminal autoprocessing of HIV-1 protease. Nature 2008, 455:693-696.

28. Martin JL, Wilson JE, Haynes RL, Furman PA: Mechanism of resistance of human immunodeficiency virus type 1 to $2^{\prime}, 3^{\prime}$-dideoxyinosine. Proc Natl Acad Sci USA 1993, 90:6135-6139.

29. Ueno T, Shirasaka T, Mitsuya H: Enzymatic characterization of human immunodeficiency virus type 1 reverse transcriptase resistant to multiple 2',3'-dideoxynucleoside 5'-triphosphates. J Biol Chem 1995, 270:23605-23611.

30. Wilson JE, Aulabaugh A, Caligan B, McPherson S, Wakefield JK, Jablonski S, Morrow CD, Reardon JE, Furman PA: Human immunodeficiency virus type-1 reverse transcriptase. contribution of met-184 to binding of nucleoside 5'-triphosphate. J Biol Chem 1996, 271:13656-13662.

31. Santos-Velazquez J, Kim B: Deoxynucleoside triphosphate incorporation mechanism of foamy virus (FV) reverse transcriptase: Implications for cell tropism of FV. J Virol 2008, 82:8235-8238.

32. Krebs R, Immendörfer U, Thrall S, Wöhrl BM, Goody RS: Single-step kinetics of HIV-reverse transcriptase mutants responsible for virus resistance to nucleoside inhibitors zidovudine and 3TC. Biochemistry (N Y) 1997, 36:10292-10300.

33. Wöhrl BM, Krebs R, Thrall SH, Le Grice SFJ, Scheidig AJ, Goody RS: Kinetic analysis of four HIV-1 reverse transcriptase enzymes mutated in the 
primer grip region of p66. implications for DNA synthesis and dimerization. J Biol Chem 1997, 272:17581-17587.

34. Gorshkova II, Rausch JW, Le Grice SF, Crouch RJ: HIV-1 reverse transcriptase interaction with model RNA-DNA duplexes. Anal Biochem 2001, 291:198-206.

35. Parniak MA, Min KL, Budihas SR, Le Grice SF, Beutler JA: A fluorescencebased high-throughput screening assay for inhibitors of human immunodeficiency virus-1 reverse transcriptase-associated ribonuclease $\mathrm{H}$ activity. Anal Biochem 2003, 322:33-39.

36. Rizzo J, Gifford LK, Zhang X, Gewirtz AM, Lu P: Chimeric RNA-DNA molecular beacon assay for ribonuclease $\mathrm{H}$ activity. Mol Cell Probes 2002, 16:277-283.

37. Werner $S$, Wöhrl BM: Soluble rous sarcoma virus reverse transcriptases $\alpha$, $\alpha \beta$ and $\beta$; purified from insect cells are processive DNA polymerases

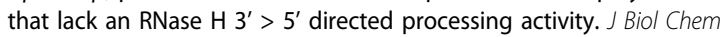
1999, 274:26329-26336.

38. Furfine $E S$, Reardon JE: Reverse transcriptase.RNase $H$ from the human immunodeficiency virus. relationship of the DNA polymerase and RNA hydrolysis activities. J Biol Chem 1991, 266:406-412.

39. Gopalakrishnan V, Peliska JA, Benkovic SJ: Human immunodeficiency virus type 1 reverse transcriptase: Spatial and temporal relationship between the polymerase and RNase $\mathrm{H}$ activities. Proc Natl Acad Sci USA 1992, 89:10763-10767.

40. DeStefano JJ, Mallaber LM, Fay PJ, Bambara RA: Quantitative analysis of RNA cleavage during RNA-directed DNA synthesis by human immunodeficiency and avian myeloblastosis virus reverse transcriptases. Nucleic Acids Res 1994, 22:3793-3800.

41. Schatz O, Mous J, Le Grice SFJ: HIV-1 RT associated ribonuclease H displays both endonuclease and $3^{\prime}->5^{\prime}$ exonuclease activities. EMBO J 1990, 9:1171-1176

42. Wöhrl BM, Moelling $\mathrm{K}$ : Interaction of HIV-1 ribonuclease $\mathrm{H}$ with polypurine tract containing RNA-DNA hybrids. Biochemistry (N Y) 1990 29:10141-10147.

43. Jacobo-Molina A, Ding J, Nanni RG, Clark AD Jr, Lu X, Tantillo C, Williams RL, Kamer G, Ferris AL, Clark P, Hizi A, Hughes SH, Arnold E: Crystal structure of human immunodeficiency virus type 1 reverse transcriptase complexed with double-stranded DNA at $3.0 \mathrm{~A}$ resolution shows bent DNA. Proc Natl Acad Sci USA 1993, 90:6320-6324.

44. Jacobo-Molina A, Clark AD Jr, Williams RL, Nanni RG, Clark P, Ferris AL, Hughes SH, Arnold E: Crystals of a ternary complex of human immunodeficiency virus type 1 reverse transcriptase with a monoclonal fab fragment and double stranded DNA diffract to $3.5 \AA$ \& resolution. Proc Natl Acad Sci USA 1992, 88:10895-10899.

45. Boyer PL, Stenbak CR, Clark PK, Linial ML, Hughes SH: Characterization of the polymerase and RNase $\mathrm{H}$ activities of human foamy virus reverse transcriptase. J Virol 2004, 78:6112-6121.

46. Cole PA: Chaperone-assisted protein expression. Structure 1996, 4:239-242.

doi:10.1186/1742-4690-7-5

Cite this article as: Hartl et al:: Biophysical and enzymatic properties of the simian and prototype foamy virus reverse transcriptases.

Retrovirology 2010 7:5.

\section{Submit your next manuscript to BioMed Central and take full advantage of:}

- Convenient online submission

- Thorough peer review

- No space constraints or color figure charges

- Immediate publication on acceptance

- Inclusion in PubMed, CAS, Scopus and Google Scholar

- Research which is freely available for redistribution

Submit your manuscript at www.biomedcentral.com/submit
Biomed Central 